\title{
The Level of Children's Independence with Cerebral Palsy in Several Regions in Java and Sumatra
}

\author{
Bambang Trisnowiyanto ${ }^{*}$, Budi Utomo ${ }^{2}$ \\ 1,2 Department of Physiotherapy, Poltekkes Kemenkes Surakarta, Indonesia \\ Email: btrisnowiyanto@gmail.com
}

\begin{abstract}
Background: The most common disorder or disability in childhood is cerebral palsy, obtained during the antenatal, perinatal or early postnatal period. Cerebral palsy is a non-progressive injury or brain lesion with very variable clinical manifestations. children with cerebral palsy have impaired movement, ability levels and functional limitations and affected body parts. Therefore, to find out the level of independence in children with cerebral palsy, it is necessary to have an examination carried out by health workers, especially physiotherapy. In this case, an examination using the Gross Motor Function Classification System (GMFCS). The purpose of this study was to determine the degree of independence of children with cerebral palsy in several regions in Java and Sumatra. Methods: A total of 315 children with cerebral palsy (mean $\pm S D$ ) participated in this cross-sectional study design. The research was conducted in March-June 2019. GMFCS data was collected from children with cerebral palsy in the parent community of cerebral palsy in 10 cities. The Kolmogorov-Smirnov test used for data normality test. Results: Overall research subjects from 10 cerebral palsy communities with a total sample of 315 children, most cerebral palsy with GMFCS level 4 as many as 117 children (37.1\%), then GMFCS level 3 as many as 84 children (26.7\%), GMFCS level 5 is 67 children (21.3\%), level 2 GMFCS is 24 children (7.6\%), and at least children with level 1 GMFCS are 23 children (7.3\%). Conclusion: The conclusion is from a total of 315 children with cerebral palsy, the level of Indonesian children's independence based on GMFCS most of them are less independent.
\end{abstract}

Keywords: independence, cerebral palsy

\section{INTRODUCTION}

Children experience growth and development processes that begin from the womb, infacy, toddler, school, age and adolescence, where in the growth and development of children can experience obstacles caused by many factors. Children who experience neurological dysfunction can cause weakness and disability with will affect the next life (Ari, 2014;Purnomo, 2013).

Cerebral palsy is a collection of motor disorders due to brain damage that occurs before, during or after birth which can be caused by many factors such as, congenital, genetic, inflation, infection and poisoning during pregnancy, trauma and metabolic disorders (Colver, Fairhurst and Pharoah, 2014). Damage to the child's brain, affects the motor system and as a result the child has poor coordination, poor balance or abnormal movement patterns or a combination of these characteristics (Morgan and McGinley, 2018;Selekta, 2018).

Congenital cerebral palsy (or cerebral palsy present from birth) has the largest proportion in cases of cerebral palsy (Selina, Priambodo and Sakundarno, 2013). In other children, injuries that occur during birth or in early childhood can be considered a cause of cerebral palsy. When motor disorders appear after age 5, they differ slightly from cerebral palsy motor disorders and are usually diagnosed as injuries to adults, such as strokes or traumatic brain injuries (A.T., K. and M., 2009; Pakula, Van Naarden Braun and Yeargin-Allsopp, 2009; Graham et al., 2016). 
The topographic classification of cerebral palsy is monoplegia, hemiplegia, diplegia and quadriplegia; monoplegia and triplegia are relatively rare (MacLennan, Thompson and Gecz, 2015). There is substantial overlap in the affected area. Cerebral Palsy (CP) is the most common motor disability disorder in children with a prevalence of 2-3 per 1000 live births (Stavsky et al., 2017). 50\% of cases are mild, namely the patient can take care of himself, and $10 \%$ is classified as severe, namely the patient requires special services. $35 \%$ are accompanied by seizures and $50 \%$ have speech problems, with an average of $70 \%$ spastic type, $10-$ $20 \%$ atetotic type, 5-10\% ataxia, and the rest are mixed type (Selina, Priambodo and Sakundarno, 2013; Gulati and Sondhi, 2018).

Cerebral palsy is not a disease entity in the traditional sense. The most common disorder or disability in childhood is cerebral palsy obtained during the antenatal, perinatal or early postnatal period. Cerebral palsy is a nonprogressive injury or brain lesion with very variable clinical manifestations. children with cerebral palsy have impaired movement, ability levels and functional limitations and affected body parts. (Liptak et al., 2011; Arshad et al., 2018).

Cerebral palsy is a term used to describe disorders of motion and posture that occur in children. Motion disorders and posture are not caused due to problems in the muscle data or nerves, but are caused by abnormalities in the brain that occur during the period of development. In other words, brain development is imperfect, whereas we know that the brain is the center of movement control (Graham et al., 2016; Shira Sender, 2019).
So from the description above, to find out the level of independence in children with cerebral palsy, it is necessary to have an examination carried out by health workers, especially physiotherapy. In this case, an examination using Gross Motor Function Measure (GMFM) and Gross Motor Function Classification System (GMFCS) (Harvey, 2017; Silva, Pfeifer and Funayama, 2013).

GMFM is a type of clinical measurement that can be done in children with cerebral palsy. Consists of 88 examination items including activities in lying and rolling positions (17 items), sitting (20 items), crawling and kneeling (14 items), standing (13 items), walking (12 items), running and jumping (12 items). There are 4 assessment scores namely $0,1,2$ and 3, each of which has the meaning $0=$ has no initiative, $1=$ initiative, $2=$ can do part, $3=$ can do the whole movement (Silva, Pfeifer and Funayama, 2013; Kenyon, 2014).

Based on the explanation above, the formulation of the problem that the author wants to point out is what is the level of independence of children with cerebral palsy in several regions in Java and Sumatra?

The goal to be achieved is to determine the level of independence of children with cerebral palsy in several regions in Java and Sumatra.

\section{METHODS}

This type of research is descriptive research which is a method of examining human status, an object, a situation or condition, system of thought, or a broad range of thoughts in the present. The purpose of this research is to research a group of people, an object, a set of 
conditions in a system of thought or broad thinking in the present with the aim of describing, describing, or describing systematically, factually, and accurately about facts, traits, and the relationship between the phenomena investigated.

The research have conducted in March-June 2019. Treatment in the form of survey data and direct examination of children with cerebral palsy in the parents' community association Cerebral palsy existing in 10 cities namely Surakarta, Karanganyar, Sragen, Yogyakarta, Mojokerto, Bandung, Bogor, Tangerang, Padang and Pekanbaru.

The subjects were 315 cerebral palsy children from 10 community associations of parents of cerebral palsy children who met the inclusion and exclusion criteria.

Inclusion criteria that must be met are as follows: (1) children with a medical diagnosis of cerebral palsy and (2) age range between 2-18 years

Exclusion criteria are (1) Cerebral palsy children who are taking part in an intervention program other than physiotherapy, (2) the presence of severe complications that interfere with motor function such as contractures and deformity, respiratory distress, and poor nutritional status.

The drop-out criteria are (1) the subject did not complete the intervention program more than twice or more during the intervention period and (2) was sick, injured, or died so as to stop the exercise program.

The variable in this study is the level of independence of cerebral palsy children, namely the ability of cerebral palsy children to perform functional activities in daily life independently.

The measuring instrument used in this study is the Expanded and Resived
Gross Motor Function Classification System (GMFCS - ER) (Kenyon, 2014). GMFCS-ER is an alternative approach to classifying cerebral palsy. Based on the concept of disability and functional limitations as determined by WHO, GMFCS-ER can be used to classify children according to their level of motor ability in the age range of 2 to 18 years. GMFCS-ER is presented in five classification classes where the higher the level, the less the ability of children. In general, the level of GMFCS-ER classification is as follows (1) level I children are able to walk without obstacles in various road terrains, (2) level II children are able to walk with obstacles on certain road terrain, (3) level III children are able to walk but using hand-held aids such as crutches, walkers or sticks, (4) level IV of child mobility is increasingly limited; where children use electrical mobility aids and need caregiver assistance in several activities, (5) level V children fully need caregiver assistance in their activities and in ambulation children must use manual wheelchairs.

Data normality test is used to determine whether the data to be analyzed is normally distributed or not. Statistical analysis is used to test the normality of data using the saphiro-wilk test if the subject is $\leq 50$. Whereas the subject of $\geq$ 50 uses the Kolmogorov-Smirnov test. The basis for decision making is if the probability $p>0.05$ then the data distribution is declared normal. If the data is normally distributed then the statistical analysis used is parametric. Conversely if $\mathrm{p}<0.05$ then the data are declared to be abnormally distributed and statistical analysis using non-parametric. The data is then analyzed with a frequency 
distribution table using the SPSS-20 Surakarta, Sragen, Karanganyar, application. Yogyakarta, Mojokerto, Bandung, Bogor, Jakarta, Padang and Pekanbaru.

\section{RESULTS}

\section{Characteristics of The Children}

The research sample is the total

The study was conducted in a multiflashlight manner in 10 cerebral palsy communities in Indonesia, namely in population of cerebral palsy children in all communities that meet the research criteria, namely the age range of 2-18 years, with a total sampling method.

\section{Table 1. Subject Distribution}

\begin{tabular}{|c|c|}
\hline City & Frequency \\
\hline Surakarta & 45 \\
\hline Sragen & 30 \\
\hline Karanganyar & 23 \\
\hline Yogyakarta & 41 \\
\hline Mojokerto & 19 \\
\hline Bandung & 37 \\
\hline Bogor & 30 \\
\hline Jakarta & 20 \\
\hline Padang & 32 \\
\hline Pekanbaru & 38 \\
\hline Amount & 315 \\
\hline $\begin{array}{l}\text { Based on the table } 1 \text {, data of } 326 \\
\text { cerebral palsy children in all communities, } \\
\text { the number of samples that met the } \\
\text { inclusion criteria was } 315 \text { children so the } \\
\text { number of samples in this study was } 315\end{array}$ & $\begin{array}{l}\text { inclusion criteria were } 11 \text { children, } \\
\text { namely } 3 \text { children over } 18 \text { years, } 2 \\
\text { children with severe respiratory distress, } \\
\text { and } 6 \text { children with complications of } \\
\text { contractures and deformities. }\end{array}$ \\
\hline
\end{tabular}

research samples that did not meet the

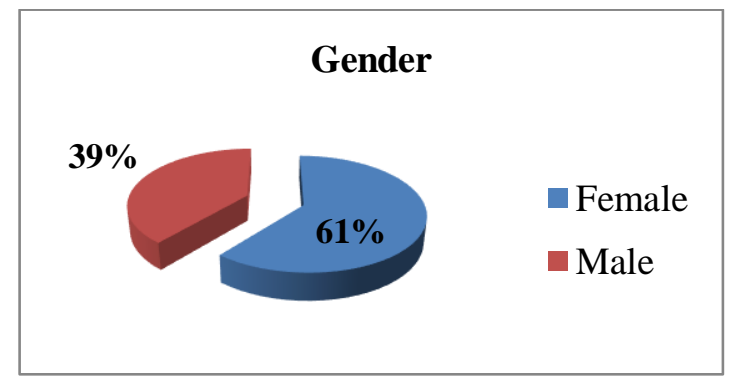

Picture 1. Distribution of Subjects by Gender

Based on the picture 1, it appears that the research subjects of 10 cerebral palsy communities are mostly male, as many as 191 children (61\%), and a small proportion are female as many as 124 children (39\%). 


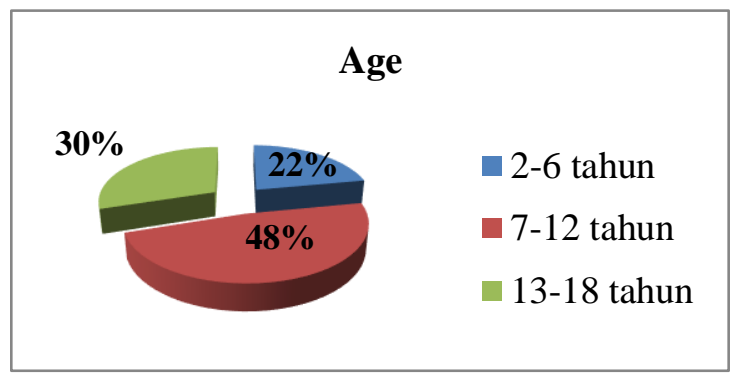

Picture 2. Distribution of Subjects by Age

Based on the picture 2, it appears 152 children (48\%), and most are early that the research subjects of the 10 childhood aged 2-6 years, namely 68 cerebral palsy communities are mostly children $(22 \%)$. late childhood aged 7-12 years, which is

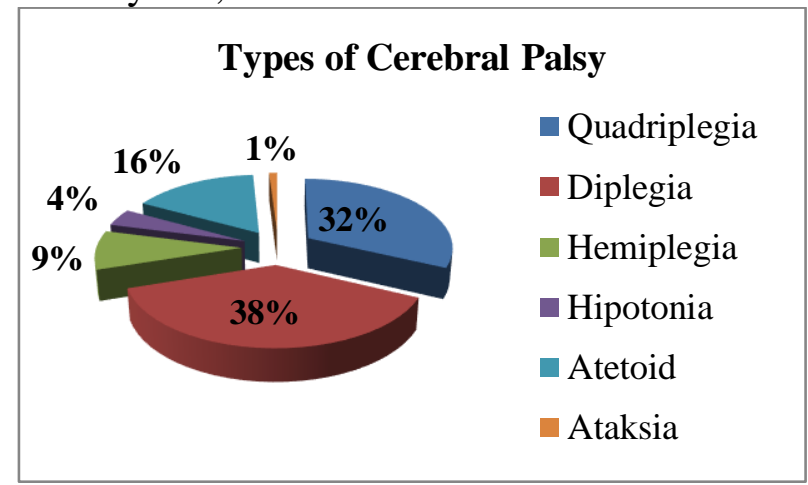

Picture 3. Distribution of Subjects Based on Types of Cerebral Palsy

Based on the picture 3, it appears (38\%), hemiplegia 27 children (9\%), that the research subjects of 10 cerebral hypotonia 12 children $(4 \%)$, athetosis 50 palsy communities are mostly children (16\%) and ataxia with 4 children quadriplegia types, as many as 103 (1\%). children $(32 \%), 119$ diplegia children

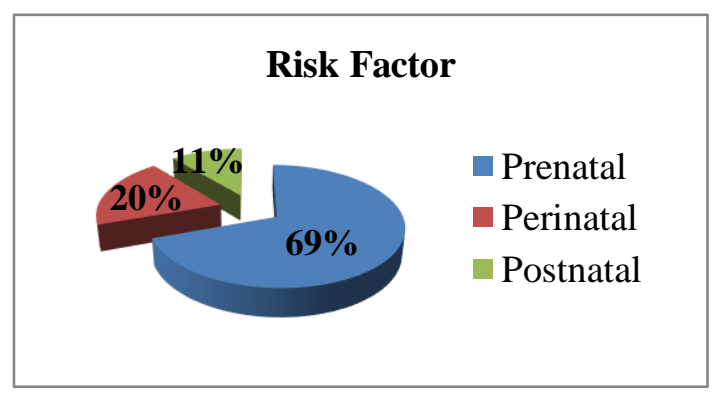

Picture 4. Distribution of Subjects Based on Risk Factors

Based on the picture 4, it appears communities are mostly cerebral palsy that the study subjects 10 cerebral palsy with prenatal risk factors of 219 children 
(69.5\%), perinatal risk factors of 61 children $(30.5 \%)$, and postnatal risk factors of 35 children (11\%).

Specific description of research results is the distribution of research subjects based on level independence of children in 10 cerebral palsy communities with the following research results:

1. Level of Independence in The Surakarta Community

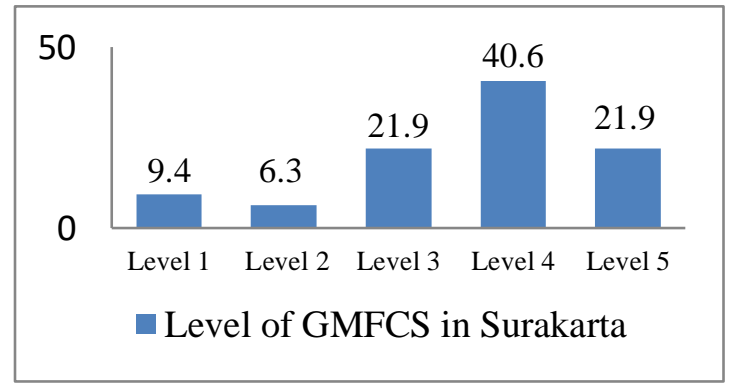

Picture 5. Distribution of Subjects in Surakarta based on GMFCS

Based on the picture 5, it appears that from the number of research subjects 32 children in the cerebral palsy community in Surakarta, most of the children with GMFCS level 4 were 13 children (40.6\%), then GMFCS levels 3 and 5 were 7 children each. (21.9\%), level
1 GMFCS is 3 children $(9.4 \%)$, and at least children with level 2 GMFCS are 2 children $(6.3 \%)$.

2. Level of Independence in The Karanganyar Community

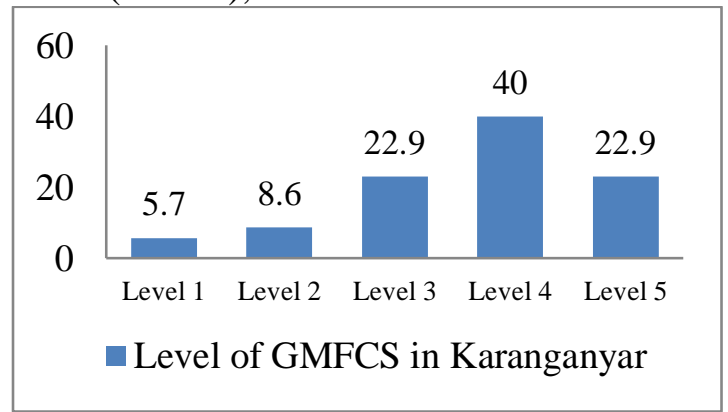

Picture 6. Distribution of Subjects in Karanganyar based on GMFCS

Based on the picture 6 , it appears that from the number of research subjects 35 children in the cerebral palsy community in Karanganyar, most of the children with GMFCS level 4 were 14 children (40.6\%), then GMFCS levels 3 and 5 namely as many as 8 children each.
(21.9\%), GMFCS level 2 as many as 3 children $(8.6 \%)$, and the least number of children with GMFCS level 1, namely 2 children $(5.7 \%)$.

3. Level of Independence in The Sragen Community 


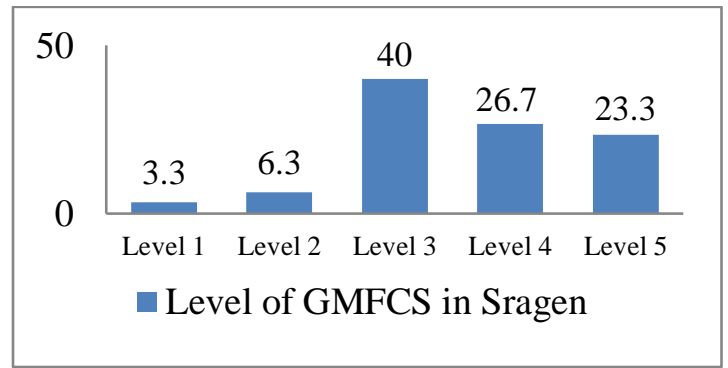

Picture 7. Distribution of Subjects in Sragen based on GMFCS

Based on the picture 7, it appears that from the number of research subjects 30 children in the cerebral palsy community in Sragen, most children with GMFCS level 3 are 12 children (40\%), then GMFCS level 4 which is 8 children
(26.7\%), GMFCS level 5 that is 7 children $(23.3 \%)$, GMFCS level 5 is as much as 2 children $(6.3 \%)$, and at least children with level 1 GMFCS are 1 child (3.3\%).

4. Level of Independence in The Yogyakarta Community

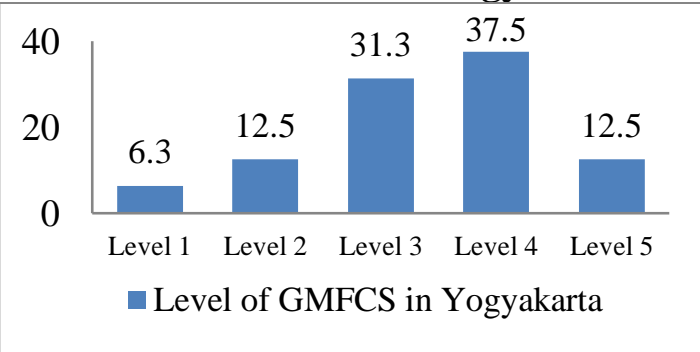

Picture 8. Distribution of Subjects in Yogyakarta based on GMFCS

Based on the picture 8 , it appears that from the number of research subjects 32 children in the cerebral palsy community in Yogyakarta, most children with GMFCS level 4 as many as 12 children (37.5\%), then GMFCS level 3, as many as 10 children (31.3\%), GMFCS level 5 are 4 children (12.5\%), Level 5 GMFCS are 4 children $(12.5 \%)$, and at least children with level 1 GMFCS are 2 children $(6.3 \%)$.

5. Level of Independence in The Mojokerto Community

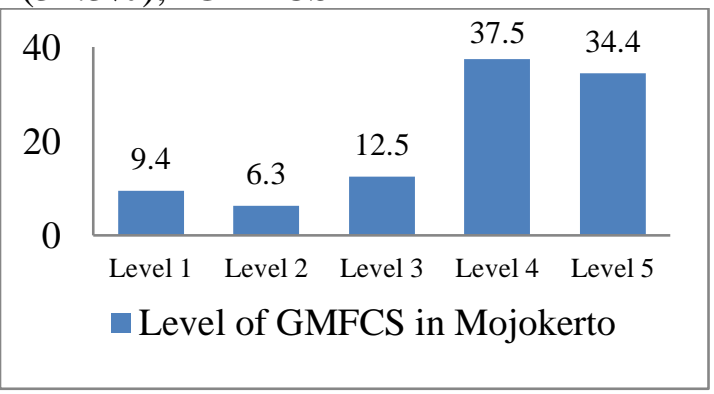

Picture 9. Distribution of subjects in Mojokerto

Based on the picture 9, it appears that from the number of research subjects 32 children in the cerebral palsy community in Mojokerto, most children with GMFCS level 4 were 12 children (37.5\%), then GMFCS level 5 was 11 
children $(34.4 \%)$, Level 3 GMFCS is 4 children $(12.5 \%)$, level 1 GMFCS is 3 children $(9.4 \%)$, and at least children with level 2 GMFCS are 2 children (6.3\%).
6. Level of Independence in The Bandung Community

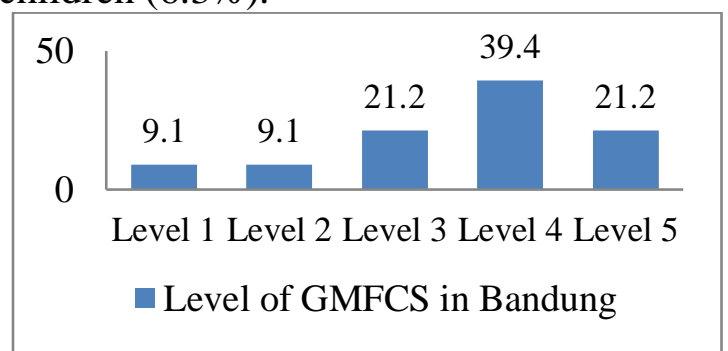

Picture 10. Distribution of Subjects in Bandung Based on GMFCS

Based on the picture 10, it appears that from the number of research subjects 32 children in the cerebral palsy community in Bandung, most of the children with GMFCS level 4 were 13 children $(39.4 \%)$, then GMFCS 4 and level 5 were 7 children each. $(21.2 \%)$, and at least children with level 2 and 1 GMFCS, namely 3 children each $(9.1 \%)$.

7. Level of Independence in the Bogor Community

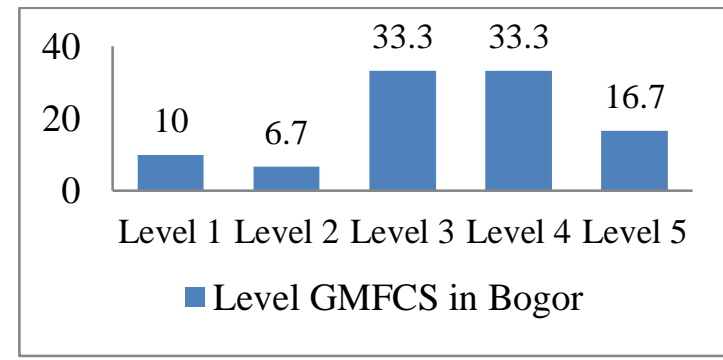

Picture 11. Distribution of Subjects in Bogor Based on GMFCS

Based on the picture 11, it appears that from the number of research subjects 30 children in the cerebral palsy community in Bogor, most of the children with GMFCS level 3 and level 5 are 10 children $(33.3 \%)$, then GMFCS level 5 is
5 children $(16,7 \%)$,Level 1 GMFCS are 3 children $(10 \%)$, and at least children with level 2 GMFCS are 2 children (6.7\%).

8. Level of Independence in the Tangerang Community

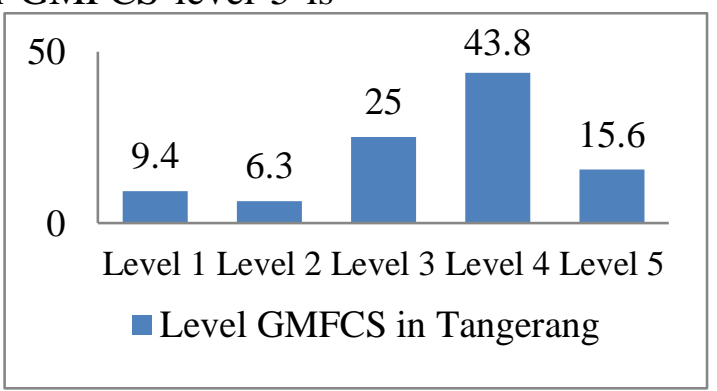

Picture 12. Distribution of subjects in Tangerang based on GMFCS 
Based on the picture 12, it appears that from the number of research subjects 32 children in the cerebral palsy community in Tangerang, most of the children $(43.8 \%)$, then GMFCS level 3 is as many as 8 children (25\%), GMFCS children with GMFCS level 4 are 14

level 5, as many as 5 children (15.6\%), level 1 GMFCS that is as much as 3 children $(9.4 \%)$, and at least children with level 2 GMFCS are as many as 2 children $(6.3 \%)$.

9. Level of Independence in the Padang Community

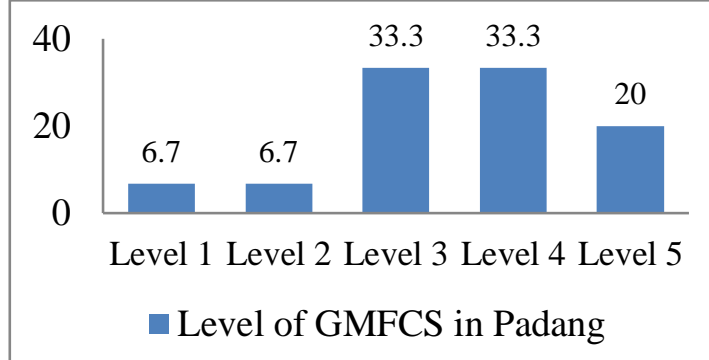

Picture 13. Distribution of Subjects in Padang Based on GMFCS

Based on the picture 13, it appears that from the number of research subjects 30 children in the cerebral palsy community in Padang, most of the children with level 3 and level 4 GMFCS were 10 children $(33.3 \%)$, then GMFCS level 5 which was 6 children (20\%), and at least children with level 1 and level 2 GMFCS are 2 children $(6.7 \%)$.

10. Level of Independence in the Pekanbaru Community

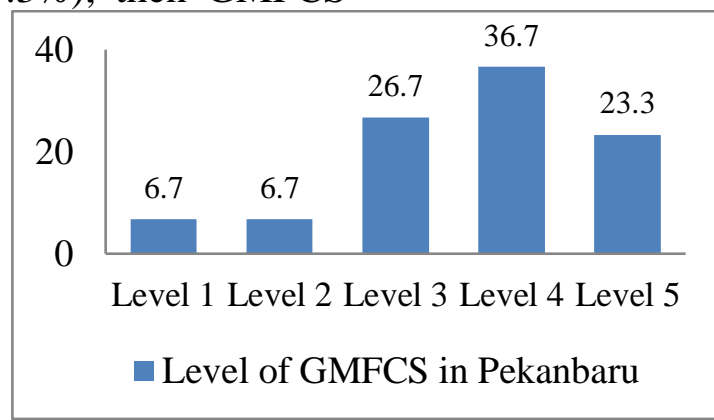

Picture 14. Distribution of subjects in Pekanbaru based on GMFCS

Based on the picture 14, it appears that from the number of research subjects 30 children in the cerebral palsy community in Pekanbaru, most children with GMFCS level 4 are 11 children
$(36.7 \%)$, then GMFCS level 3 is as many as 8 children $(26.7 \%)$, GMFCS level 5 is 7 children $(23.3 \%)$, and at least children with level 1 and level 2 GMFCS are 2 children $(6.7 \%)$. 


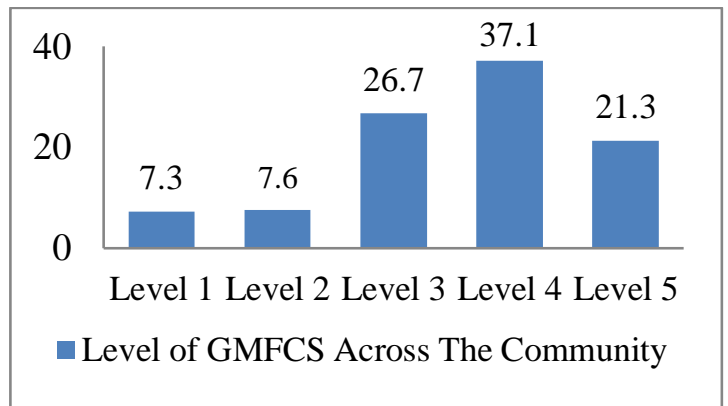

Picture 15. Distribution of Subjects Throughout The Community based on GMFCS

Based on the picture 15, it appears that from the overall research subjects of 10 cerebral palsy communities with a total sample of 315 children, most cerebral palsy with GMFCS level 4 are 117 children $(37.1 \%)$, then GMFCS level 3 is 84 children (84 children) $26.7 \%$ ), GMFCS level 5 with 67 children (21.3\%), GMFCS level 2 with 24 children (7.6\%), and at least children with GMFCS level 1 with 23 children $(7.3 \%)$.

\section{DISCUSSION}

After conducting a multi-center research nationally in 10 cerebral palsy communities in Indonesia, based on gender criteria, the cerebral palsy children studied were mostly male, as many as 191 children $(61 \%)$, and a small proportion were female as many as 124 children $(39 \%)$.

Cerebral palsy and other nervous system development disorders from epidemiological studies are more common in boys compared to girls, but the clinical reasons for these differences are not known with certainty. Based on research in children with boys with preterm birth showed that brain tissue was more susceptible to damage to albedo subsatansia and the occurrence of intraventicular bleeding (A.T., K. and M., 2009).
Research shows the results that hormonal factors and neuroprotective factors in the nervous system show different responses in men and women, and the results of other studies provide information that there are differences in the response of neurobiological systems to nerve tissue injuries between men and women (A.T., K. and M., 2009).

Based on age criteria, most of the cerebral palsy children studied were late childhood aged 7-12 years, namely 152 children (48\%), and some were early childhood aged 2-6 years, namely 68 children (22\%).

Based on the criteria of cerebral palsy type, most of the children studied were quadriplegia with 103 children (32\%), diplegia 119 children (38\%), hemiplegia 27 children (9\%), 12 child hypotonia (4\%), athetosis 50 children $(16 \%)$ and ataxia 4 children $(1 \%)$.

Based on the criteria of risk factors that cause cerebral palsy of cerebral palsy children, most of the cerebral palsy with 219 prenatal risk factors $(69.5 \%)$, perinatal risk factors of 61 children $(30.5 \%)$, and 35 postnatal risk factors children (11\%),

Based on the results of statistical tests with chi square obtained $\mathrm{p}=0.016$ then $\alpha=0.05$ is greater than 0.016 , which means there is a significant relationship between the nutritional status of children 
with motor development of cerebral palsy children. From the results of the analysis also obtained the value of $\mathrm{OR}=3.52$ which means that children with good nutritional status have a 3.52 times chance to obtain good motor development (Beckung et al., 2008).

The incidence of cerebral palsy based on spastic $\mathrm{CP}$ is the most common type with a prevalence of $70 \%$. Diskenic CP includes dystonia and atetoid of 1015\%. Ataxia CP occurs at least 5\%. Understanding mild motor deficits are patients who can take care of themselves, while those classified as severe motor deficits are sufferers who cannot take care of themselves need special care (Reddihough, 2011).

The incidence of cerebral palsy from studies conducted in Europe obtained a prevalence of 5 out of 1000 children showing motor deficits corresponding to cerebral palsy; $50 \%$ of cases are severe, while $10 \%$ are mild. Understanding mild moral deficits are patients who can take care of themselves, while those classified as severe motor deficits are sufferers who cannot take care of themselves need special care (A.T., K. and M., 2009).

\section{CONCLUSION}

Based on the results of the study and the results of data processing with frequency tables, from a total of 315 cerebral palsy children who were studied multi-flashlight 10 communities namely in Surakarta, Sragen, Karanganyar, Yogyakarta, Mojokerto, Bandung, Bogor, Jakarta, Padang and Pekanbaru, the level of children's independence based on GMFCS most of them are less independent.

This research is a descriptive study that has obtained the frequency distribution and percentage of aspects studied, namely the level of children's independence based on GMFCS, for further researchers should conduct experimental research by intervening in children with cerebral palsy with the aim of increasing the level of children's independence.

\section{REFERENCES}

A.T., P., K., V. N. B. and M., Y.-A. (2009). 'Cerebral Palsy: Classification and Epidemiology', Physical Medicine and Rehabilitation Clinics of North America.

Ari, S. (2014).Deteksi Tumbuh Kembang Anak, Salemba Medika.

Arshad, N. et al. (2018) 'SPASTICEREBRAL PALSY ', The Professional Medical Journal. doi: $10.29309 / \mathrm{tpmj} / 18.4614$.

Beckung, E. et al. (2008). 'Health status of children with cerebral palsy living in Europe: A multi-centre study', Child: Care, Health and Development. doi: 10.1111/j.13652214.2008.00877.x.

Colver, A., Fairhurst, C. and Pharoah, P. O. D. (2014) 'Cerebral palsy', in The Lancet. doi: 10.1016/S01406736(13)61835-8.

Graham, H. K. et al. (2016) 'Cerebral palsy', Nature Reviews Disease Primers. doi: 10.1038/nrdp.2015.82.

Gulati, S. and Sondhi, V. (2018) 'Cerebral Palsy: An Overview', Indian Journal of Pediatrics. doi: 
10.1007/s12098-017-2475-1.

Harvey, A. R. (2017).'The Gross Motor Function Measure (GMFM)', Journal of Physiotherapy. doi: 10.1016/j.jphys.2017.05.007.

Kenyon, L. K. (2014) 'Gross Motor Function Measure (GMFM-66 and GMFM-88) Users' Manual,' Physical \& Occupational Therapy In Pediatrics. doi: 10.3109/01942638.2014.931744.

Liptak, G. S. et al. (2011).'Providing a primary care medical home for children and youth with cerebral palsy', Pediatrics. doi: 10.1542/peds.2011-1468.

MacLennan, A. H., Thompson, S. C. and Gecz, J. (2015). 'Cerebral palsy: Causes, pathways, and the role of genetic variants', American Journal of Obstetrics and Gynecology. doi: 10.1016/j.ajog.2015.05.034.

Morgan, P. and McGinley, J. L. (2018).'Cerebral palsy', in Handbook of Clinical Neurology. doi: 10.1016/B978-0-444-639165.00020-3.

Pakula, A. T., Van Naarden Braun, K. and Yeargin-Allsopp, M. (2009). 'Cerebral Palsy: Classification and Epidemiology', Physical Medicine and Rehabilitation Clinics of North America.

Purnomo, H. (2013). 'Peran Orang Tua dalam Optimalisasi Tumbuh Kembang Anak untuk Membangun
Karakter Anak Usia Dini', Prosiding Seminar Nasional Parenting.

Reddihough, D. (2011). 'Cerebral palsy in childhood', Australian Family Physician. doi: 10.1176/ajp.115.9.845.

Selekta, M. C. (2018). 'Cerebral Palsy Tipe Spastik Quadriplegi Pada Anak Usia 5 Tahun Cerebral Palsy Spastic Quadriplegic Type on Child 5 Years Old', Majority, 7(3), pp. 186-190.

Selina, H., Priambodo, W. and Sakundarno, M. (2013). 'Gangguna Tidur Pada Anak Palsi Serebral', Medica Hospitalia: Journal of Clinical Medicine. doi: 10.36408/mhjcm.v1i2.54.

Shira Sender, J. (2019). 'Cerebral Palsy: A Complete Guide for Caregiving', Journal of Consumer Health on the Internet. doi: 10.1080/15398285.2019.1582252.

Silva, D. B. R., Pfeifer, L. I. and Funayama, C. A. R. (2013). 'Gross motor function classification system expanded \& revised (GMFCS E \& $\mathrm{R})$ : Reliability between therapists and parents in Brazil', Brazilian Journal of Physical Therapy, 17(5).

Stavsky, M. et al. (2017). 'Cerebral palsytrends in epidemiology and recent development in prenatal mechanisms of disease, treatment, and prevention', Frontiers in Pediatrics. 